\title{
QUANTITATIVE DATA ABOUT CORAL RECRUITMENT FROM BUNAKEN ISLAND, MANADO INDONESIA
}

\author{
Marina F.O Singkoh \\ Staf Pengajar pada Fakultas Matematika dan IImu Pengetahuan Alam. \\ UNSRAT. Manado 95115.
}

\author{
ABSTRACT \\ Singkoh, M.F.O., 2010. Data Kuantitatif Perekrutan Karang di \\ Pulau Bunaken, Manado Indonesia. \\ Jurnal Perikanan dan Kelautan. Vol VI (1): 67-71.
}

\begin{abstract}
Tujuan penelitian ini adalah untuk menentukan kepadatan pf rekrutmen karang di berbagai lokasi di Pulau Bunaken dan analis interaksi pada rekrutmen karang didasarkan pada kuantitas, kedalaman dan situs. Penelitian dilakukan di kedalaman 3 dan 10 meter dan tiga direplikasi di setiap kedalaman. Kami menggunakan metode sabuk tansect. Jalur ini $50 \mathrm{~m}$ dan lebar $1 \mathrm{~m}$ kanan dan $1 \mathrm{~m}$. Jadi daerah penelitian adalah $2 \times 50=100 \mathrm{~m}^{2}$. Ketika dilakukan penelitian kita berenang zigzag dan menghitung setiap perekrutan karang yang temukan. Kami ukur setiap merekrut karang yang temukan di analisa dan dicatat setiap pengukuran pada papan tulis bawah air. Ukuran karang adalah $<5 \mathrm{~cm}$. Dari penelitian yang dilakukan, jumlah rekrutmen karang yang ditemukan adalah 96 koloni. Koloni ini ditemukan di tiga lokasi yaitu Liang sebagai situs I (27 koloni), Tawara sebagai situs II (30 koloni) dan Zona Inti sebagai Situs III (39 koloni). Kepadatan tertinggi di zona inti pada kedalaman 3 meter. Sebagai kesimpulan, rekrutmen karang dapat berkembang dengan baik di kedalaman $3 \mathrm{~m}$ atau kurang dari $3 \mathrm{~m}$, juga di wilayah yang kurang atau tidak ada aktivitas manusia. bagaimanapun, faktor-faktor lain seperti fisik, kimia dan faktor biologis juga memainkan peranan penting dalam perkembangan karang.
\end{abstract}

Kata kunci: Perekrutan karang, Bunaken.

\section{INTRODUCTION}

The natural biodiversity of coral reef has been interesting for the scientist and tourist long time ago. Coral reef is one of the unique association communities of tha sea. Although coral is the superior organism who are related/association with the coral, take part in coral reef community.

Coral reef of Bunaken at North Sulawesi is one of a potential coral reef in Indonesia. The geography of Bunaken Island is Between $1^{0} 35^{\prime} 50^{\prime \prime}-1^{0} 38^{\prime} 15^{\prime \prime} \mathrm{N}$ and $124^{\circ} 43^{\prime} 25^{\prime \prime}-124^{\circ} 46^{\prime} 75^{\prime \prime} E$.

Measuring recruitment patterns of marine organisms is of fundamental importance for understanding the mechanisms that regulate their populations and mediate species coexistence (Underwood, 1989). In addition to understanding population dynamics, knowledge of recruitment patterns is a prerequisite fot the effective management of marine ecosystems, enabling informed responses to disturbances, such as crown of the thorns starfish outbreaks, storms and bleaching events (Hughes, 1999). The importance of monitoring processes such as recruitment, rather than just changes in adult abundance, in order to understand how reef ecosystems function, is becoming increasingly clear. Consequently, measuring changes in patterns of settlement and recruitment may provide an early warning of potential damage of reefs or impacts on their resilience after disturbance (Babcock, 2003).

The complex community dynamics of coral reefs includes the influence of disturbances on community structure and population dynamics. Within ecological 
communities, the abundance of juvenile stages proud insight into the future diversity and abundance of corals in an area and in to the community's long term response to disturbance. Life history strategies, competition, predation and disturbance will all affect the abundance and distribution of recruit's coral are small at settlement and growth is slow. Consequently a year of more may pass before a recruit is visible on the reef substratum.

It is important to do the research about coral recruitment so we can know the development of coral. As we know there so many reason can hold the development of coral. Example human activities, bleaching proses and desease (White band disease and Black band disease). The backround of this research generally is to see the development of colony coral at Bunaken Island. Cause we know there is a lot of human activities in Bunaken Island. Beside the local people activities they had a visitors activities. There is possible to have a high coral damage. Now Bunaken Island devide in several zone. They have tourism zone, community zone and core Zone. From this research we hope we can see the different quantitation of coral recruitment in each zone.

The aims of the project, are:

1. To determine density of coral recruitment at various locations in Bunaken Island.

2. To anlys the interaction on coral recruitment based on quantity, depth and site.

\section{RESEARCH METHODOLOGY}

The location of this research was firstly chosen. The location was chosen to be the Core zone and Liang and Tawara were chosen to be the other locations.

Research was done at the $3 \mathrm{~m}$ and $10 \mathrm{~m}$ depth an three replication in every depth. We use belt transect method, so we could know the density. The line was 50 $\mathrm{m}$ and thw wide is $1 \mathrm{~m}$ right and $1 \mathrm{~m}$ left. So the surface research area was $2 \times 50=$ $100 \mathrm{~m}^{2}$. When we did the research we swam zigzag and count every coral recruitment we found.

We measured every coral recruit we found in the area research and we noted/wrote every measurement in the underwater slates with pencil. The measure of coral is $<5 \mathrm{~cm}$.

Before doing this research we must prepare the equipment needed to do the research, including the equipment of scuba diving.

\section{RESULT AND DISCUSSION}

From the research conducted in Bunaken island, the number of coral recruit found was 96 colonies. These colonies were found in three locations which were Liang as Site I (27 colonies), Tawara as Site II (30 colonies) and Core zone area as Site III(39 colonies).

Table 1. Total Coral Recruitment

\begin{tabular}{|c|c|c|c|c|c|c|c|}
\hline \multirow{3}{*}{$\begin{array}{c}\text { Class } \\
\text { Interval } \\
\text { (cm) }\end{array}$} & \multicolumn{6}{|c|}{ Location/depth (m) } & \multirow{3}{*}{ Total } \\
\hline & \multirow{2}{*}{\multicolumn{2}{|c|}{$\begin{array}{l}\text { Liang } \\
3 \quad 10\end{array}$}} & \multirow{2}{*}{\multicolumn{2}{|c|}{$\begin{array}{c}\text { Tawara } \\
3 \quad 10\end{array}$}} & \multicolumn{2}{|c|}{ Core Zone } & \\
\hline & & & & & 3 & 10 & \\
\hline $0-1$ & 1 & 1 & 1 & 1 & 1 & 1 & 6 \\
\hline $1-2$ & 7 & 1 & 5 & 3 & 5 & 3 & 24 \\
\hline $2-3$ & 7 & 2 & 6 & 3 & 9 & 6 & 33 \\
\hline $3-4$ & 2 & 3 & 2 & 2 & - & - & 9 \\
\hline $4-5$ & 1 & 2 & 2 & 5 & 7 & 7 & 24 \\
\hline Total & 18 & 9 & 16 & 14 & 22 & 17 & 96 \\
\hline
\end{tabular}


By using the density calculation (Cox, 1967), the result can be presented as follows:

As is shown in table 2, the highest density is Core zone area at $3 \mathrm{~m}$ depth. Coral recruitment can grow well because sun ray can be received and absorbed for its development.

According to the Engelhardt (2002) the age of coral recruitment can be injerred from the length categories are as follows:

Based on table 3 the result of the research can be categories in 3 groups as is shown in table 4.

From table 4 it is clear that coral recruitment of $2-5 \mathrm{~cm}$ is found more frequent than is counter parts $(0-1$ and $1-2 \mathrm{~cm})$. The reason is that the 2 years old can stand against deseases, algae or even waves and current.

Figure 1 shows that coral recruitments is found mostly in the depth of $3 \mathrm{~m}$ especially those which are $2-5 \mathrm{~cm}$ long.

From figure 2, coral recruitment having length of $0-1 \mathrm{~cm}$ and $1-2 \mathrm{~cm}$ was the same in the 3 site. But coral recruitment having length $2-5 \mathrm{~cm}$ was different in 3 locations, coral recruitment is found mostly in core zone area.

Table 4. Total of Length and Age in Coral Recruitment

\begin{tabular}{|c|c|c|c|c|c|c|c|c|}
\hline \multirow{2}{*}{$\begin{array}{c}\text { Class } \\
\text { Interval } \\
\text { (cm) }\end{array}$} & \multirow{2}{*}{$\begin{array}{c}\text { Age } \\
\text { (Year) }\end{array}$} & \multicolumn{6}{|c|}{ Location/depth (m) } & \multirow[t]{2}{*}{ Total } \\
\hline & & \multicolumn{2}{|c|}{ Liang } & \multicolumn{2}{|c|}{ Tawara } & \multicolumn{2}{|c|}{ Core Zone } & \\
\hline & & 3 & 10 & 3 & 10 & 3 & 10 & \\
\hline $0-1$ & $<1$ & 1 & 1 & 1 & 1 & 1 & 1 & 6 \\
\hline $1-2$ & 1 & 7 & 1 & 5 & 3 & 5 & 3 & 24 \\
\hline $2-5$ & 2 & 10 & 7 & 10 & 10 & 16 & 13 & 66 \\
\hline Total & & 18 & 9 & 16 & 14 & 22 & 17 & 96 \\
\hline
\end{tabular}
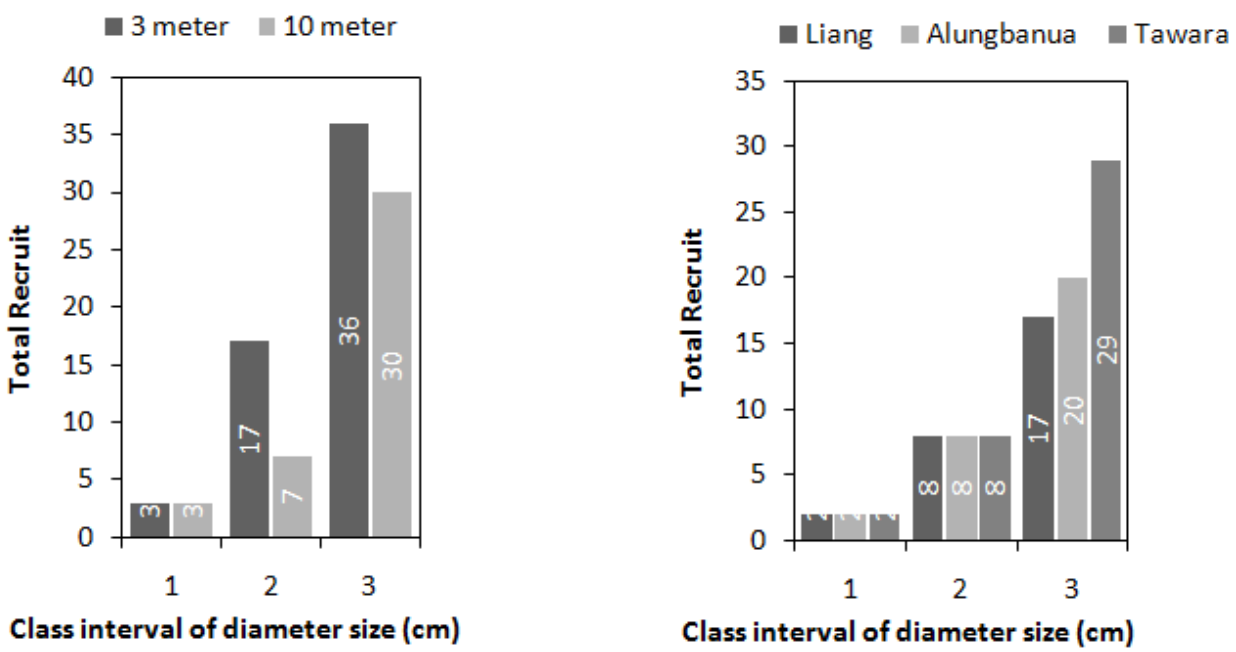

Figure 1. Comparison based on depth. Figure 2. Comparison based on Location 
The existence of coral recruitment is determined by several factors that enable it to live. According to Lachmudin (1982), these factors are:

a. Physical factors : current, tide, temperature, visibility, wave, depth and sediment.

b. Chemical factors : Salinity, $\mathrm{CO}_{2}, \mathrm{O}^{2}, \mathrm{PH}$.

c. Biological factors : Food, competition, number of zooxanthellae on corals polyp.

Moka (1984) says that behavior and activities can also affect the development of corals. South Bunaken where the research was conducted is guite a save place because it is protected from current and waves from open sea can give negative effect on corals development. How ever human activities in this area are so hight that threaten the coral. Coral recruitment was mostly found in core zone area because human activity in this area only for research purpose. Different case happens in Liang and Tawara were there is no restriction in human activities. These activities grow in number along with the increase in number of visitors and the number of local people activities. The increasing popularity of scuba diving has put more strain on coral reefs around the world. Divers frequently make contact with fragile corals, breaking them or damaging their fragile tissue surface leaving tem susceptible to bacterial attack and disease (Rouphael and Ingis, 2001). That is why the number of coral recruitment on Tawara and Liang is lesser than in core zone area.

Coral reefs are among the most productive ecosystems in the world. In order to exploit their potential in the environments in which they are found, we need to know much more about the mechanisms underlying their recruitment, growth, and behaviour, particularly under conditions of stress. Recent studies of recruitment suggest that high juvenile mortality is a key factor in the restructuring of coral communities (Crabbe, 2001). Coral reef have existed for approximately 450 milion years and are one of the most diverse ecosystems in the world (Viles and Spencer, 1995). They are often referred to as rainforest of the ocean and are home to a wide variety of marine organisms. Coral reef provide natural barriers that protect coastlines from tides, storms and hurricanes. They dissipate the wave energy and decrease the destructive stress upon the coast (Sorokin, 1993). That is why we must protect the coral.

\section{CONCLUSSION}

As a conclusion, coral recruitment can develop well at $3 \mathrm{~m}$ deep area and also in less or no human activities area. How ever other factors such as physical, chemical and biological factors also play important rules in the development of coral. 2- $5 \mathrm{~cm}$ long coral recruitments are found more frequent because they are strong enough to survive. Maybe can strong enough to survive from wave, current or disease but how about human activities? So we should remember that the development of coral depend on the management of human.

From this research we have the data and data say that is a different quantitation of coral recruitment in Core zone and out of Core zone. But this research only take 3 location from Bunaken island, in the next period we hope there is a research about coral recruitment in other location. So it can complete this research, and with different method in the future may we have a more specific research about coral recruitment.

\section{REFERENCES}

Bak, RPM and Engel MS 1979. Distribution, Abundance, and Survival of Juvenile Hermatypic Corals (Scleractinia) and The Importance of Life History Strategies in The Parent Coral Community, Marine Biology 54: 341-352. 
Crabbe., 2001 Coral Growth and Recruitment. London Zoological Society.

Connel, JH 1978. Diversity In Tropical Rainforests and Coral Reefs High Diversity of Trees and Coral in Maintained only in a Nonequilibrium State. Science 199: 1302-1310.

Cox, G.W., 1967. Laboratory Manual of General Ecology. Wm.C. Brown Company Publisher. USA.165p.

Engelhardt., 2002 Monitoring Protocol for Assesing The status and Recovery Potensial of Scleractinian Coral Communities on Reefs Affected By Major Ecological Disturbances. Australia. www.sc/coral.rep.htm

Hughes TP, AH Baird, EA Dinsdale, NA Molts Chaniwzkyj, MS Pratchett, JE Tanner, BL Willis. 1999. Patterns of Recruitment and Abundance of Corals along the Great Barrier Reef. Nature 397 : 59-63.

Lachmudin, S., 1982. Karang (Determinasi Genus) Universitas Dipenogoro Semarang. 94 hal.

Miriam Huitric and Melanie Mc Field., 2000. Effect of Multiple disturbances on Dard Coral Recruits in Glovers Reef Atoll's Lagoon, Belize. 20p.

Russ C. Babcock, Andrew H. Baird, Srisakul Promvaragom Damian P. Thomson and Bette L. Willis., 2003. Identification of Scleractinian Coral Recruits from Indo Pasific Reefs. Zoological Studies.

Sorokin, YI 1993 Coral Reef Ecology. Springer. Verlag. New York.

Underwood AJ, PG Fairweather, 1989. Supply-side Ecology and Benthic Marine Assemblages Trends Ecol. Evol.

Viles, H and T Spences 1995. Coral Reefs Coastal Problem; Geomorphology, Ecology and Society at the Coast. Edward Arnold, London. 